\title{
The Clinicopathologic Features and the Factors Associated with the Survival in Light -Chain Amyloidosis Patients: A Single Center Descriptive Study
}

\author{
Hafif Zincir Amiloidozlu Hastalarda Klinikopatolojik Özellikler ve \\ Sağkalım ile Illişkili Faktörler: Tek Merkezden Tanımlayıcı Çalışma

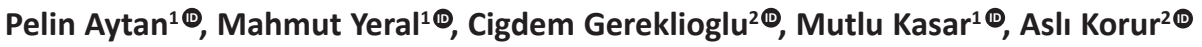 \\ Nurhilal Buyukkurt ${ }^{1 \oplus}$, Suheyl Asma ${ }^{2 \oplus}$, Ilknur Kozanoglu ${ }^{1 \oplus}$, Hakan Ozdogu $^{1 \oplus}$, Can Boga ${ }^{1 \oplus}$
}

${ }^{1}$ Adana Baskent University Faculty of Medicine, Department of Hematology, Adana, Turkey

${ }^{2}$ Adana Baskent University Faculty of Medicine, Department of Family Medicine, Adana, Turkey

Received: 15.04.2020 / Accepted: 28.07.2020 / Published Online: 30.09.2020

Cite as: Aytan P, Yeral M, Gereklioglu C, Kasar M, Korur A, Buyukkurt N, Asma S, et al. The clinicopathologic features and the factors associated with the survival in light -chain amyloidosis patients: a single center descriptive study. Med J Bakirkoy 2020;16(3):248-55.

\begin{abstract}
Objective: To present the clinicopathologic features and assess the factors related to the survival in light-chain amyloidosis (AL) patients. Method: All the patients with AL diagnosis being followed-up in the hematology department were recruited in the study. Clinicopathologic data were obtained. Factors related with overall survival (OS) including systemic inflammatory response markers were analyzed.

Results: In 16 AL patients, the estimated OS was $58.6 \pm 10.8$ months, with a-5-year-survival rate of $52.1 \%$. While, $43.8 \%$ of the patients died during the study period. Gastrointestinal and respiratory complaints were the most frequent symptoms. Myocardial and renal biopsies were amyloid positive in $31.3 \%$ and $25 \%$ of the patients respectively. Myeloma was diagnosed in $18.8 \%$ and amyloid was positive in $31.3 \%$ of the bone marrow biopsies. There was no difference between surviving and deceased patients with respect to laboratory findings including systemic inflammatory markers. Only immunoglobulin $M$ was significantly lower in the deceased patients and lgM was found to be the only factor independently associated with OS. Lower IgM levels were associated with decreased OS. An IgM value of $75.4 \mathrm{mg} / \mathrm{dL}$ was found as a cut-off value with a sensitivity and specificity of $71.4 \%$ and $66.7 \%$ respectively for the prediction of survival status.

Conclusion: AL is a rare, progressive, systemic disease with a wide spectrum of clinical presentations. The disease most commonly presents with gastrointestinal and respiratory complaints. IgM level seems to be an independent predictor of survival and may be used as a prognostic marker.
\end{abstract}

Keywords: light chain amyloidosis, AL, Immunoglobulin M, neutrophil- to- lymphocyte ratio, platelet -to- lymphocyte ratio, systemic inflammatory response markers

öz

Amaç: Hafif zincir amiloidozlu (AL) hastalarda klinikopatolojik özelliklerin ortaya konması ve sağ kalım ile ilişkili faktörlerin değerlendirilmesi. Yöntem: Hematoloji kliniğinde takip edilen tüm AL tanııı almış hastalar çalışmaya dahil edildi. Klinikopatolojik veriler toplandı. Hayatta olan hastalar ile ölmüş olan hastalar karşılaştıııldı. Toplam sağ kalım ile ilişkili faktörler, sistemik inflamatuvar belirteçler de dahil olmak üzere analiz edildi.

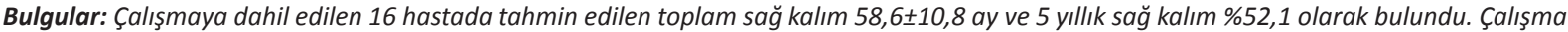
süresinde hastaların \%43,8'i öldü. En sık görülen şikayetler gastrointestinal ve respiratuvar semptomlardı. Miyokard ve renal biyopsilerde amiloid hastaların sırasıyla \%31,3 ve \%25'inde pozitif olarak bulundu. Kemik iliği değerlendirmesinde hastaların \%18,8'inde miyelom tespit edildi ve amiloid kemik iliği biyopsilerinin \%31,3'ünde pozitif idi. Hayatta kalan ve ölen hastalar arasında sistemik inflammatuvar belirteçler açısından fark yoktu. Sadece immunoglobulin M'nin ölen hastalarda daha anlamlı olarak düşük olarak bulundu ve IgM toplam sağ kalım ile bağımsız olarak ilişkili tek faktör olarak bulundu. Daha düşük IgM seviyeleri azalmış toplam sağ kalım ile ilişkili idi. IgM için 75,4 mg/dL eşik değerinin hayatta kalma ön görüsü için \%71,4 sensitivite ve \%66,7 spesifisiteye sahip olduğu bulundu.

Sonuç: AL geniş bir klinik yelpazeye sahip, nadir görülen, ilerleyici, sistemik bir hastalıktır. Hastalık en sık gastrointestinal ve respiratuvar şikayetlerle kendini gösterir. IgM sağ kalım için bağımsız bir ön gördürücü olarak görülmektedir ve prognostik bir belirteç olarak kullanılabilir.

Anahtar kelimeler: hafif zincir amiloidoz, AL, immunoglobulin M, nötrofil lenfosit oranı, platelet lenfosit oranı, sistemik inflamatuar yanıt belirteçleri

Corresponding Author:

drpelinaytan@gmail.com
P. Aytan 0000-0002-4213-1565

M. Yeral 0000-0002-9580-628X

C. Gereklioglu 0000-0003-3556-9865

M. Kasar 0000-0003-3856-7005

A. Korur 0000-0002-5086-5593
N. Buyukkurt 0000-0002-0895-4787 S. Asma 0000-0001-5335-7976

I. Kozanoglu 0000-0002-5268-1210

H. Ozdogu 0000-0002-8902-1283 C. Boga 0000-0002-9680-1958

(C) Telif hakkı Sağlık Bilimleri Üniversitesi Bakırköy Dr. Sadi Konuk Eğitim ve Araştırma Hastanesi'ne aittir. Logos Tıp Yayıncılık tarafindan yayınlanmaktadır. Bu dergide yayınlanan bütün makaleler Creative Commons Atff-GayriTicari 4.0 Uluslararası Lisansı ile lisanslanmıştı.

(c) Copyright Health Sciences University Bakırköy Sadi Konuk Training and Research Hospital. This journal published by Logos Medical Publishing.

Licenced by Creative Commons Attribution-NonCommercial 4.0 International (CC BY) 


\section{INTRODUCTION}

Light-chain amyloidosis (AL) is defined as "primary amyloidosis" which results from extra-cellular deposition of fibril-forming monoclonal immunoglobulin light chains or a fragment of the light chain usually produced by a clonal population of plasma cells in the bone marrow. It is the most common form amyloidosis with an incidence estimated to be around 1 to 4.5 cases per $100,000{ }^{(1)}$; however, the studies from autopsies have suggested a higher incidence (2). In USA, about 2500 patients are diagnosed as having AL every year ${ }^{(3)}$. It has been reported to be seen 5-10 times less frequently than multiple myeloma with an incidence rate similar to that of Hodgkin's lymphoma or chronic myelogenous leukemia ${ }^{(4,5)}$.

AL amyloidosis is usually a systemic disease characterized by multiple organ and tissue involvement as the pathologic, insoluble fibrils may deposit extracellularly in various tissues and organs. Deposition may impair the function of the affected organ or tissue. Any organ may be effected, heart, kidney, liver and nervous system being the most commonly involved ones. In United Kingdom AL constitutes $68 \%$ of all the amyloid cases and heart and kidney are the most frequently affected organs, followed by liver and nervous system ${ }^{(6-9)}$. Therefore, the disease spectrum is broad, ranging from mild symptoms to life threatening disorders including restrictive cardiopathy which is considered to be responsible from the mortality in most of the cases ${ }^{(8)}$.

There are relatively few studies on this rare systemic disease. Because symptoms are nonspecific and early diagnosis and treatment prolongs survival, studies that present clinical features are important. In this study we aimed to present the clinicopathologic features and assess the factors related to the survival in AL patients.

\section{MATERIAL and METHOD}

A single-center retrospective, non-randomized study was conducted in Başkent University Hospital Department of hematology. All the patients with the diagnosis of amyloidosis who were followed-up in the hematology department between January 2014 and July 2019 were recruited. Patients younger than
18 years and whose diagnosis was not light-chain amyloidosis were excluded. A total of 16 patients were identified. Data were obtained from the hospital's electronic database and patients' files. Institution's ethical approval was obtained for the study (KA19/284).

The diagnosis of amyloidosis was suspected when there were clinical signs and symptoms and when immunoglobulin free light- chain abnormalities were detected in immunofixation blood tests. Noninvasive diagnostic criteria of the consensus for amyloidrelated organ involvement were used for evaluation ${ }^{(10,11)}$. However the definitive diagnosis was based on the examination of the histological samples. Tissue biopsies were obtained from the involved organs whenever possible. The evaluation processes included upper gastrointestinal endoscopy, colonoscopy, cardiac biopsy, renal biopsy, bone and bone marrow biopsies. Light microscopic examination finding of amorphous extracellular Congo- red positive deposits, which display characteristic dichroism and apple green birefringence under polarized light confirmed the definitive diagnosis. In order to exclude multiple myeloma, bone marrow assessment was performed.

Chemotherapy consisted of vincristine, doxorubicin, dexamethasone (VAD), bortezomib, cyclophosphamide, dexamethasone (VCD), rituximab, bortezomib, lenalidomide, dexamethasone (R-BORD) and colchium.

The main outcome to be assessed was overall survival which was calculated from the time of diagnosis to death from any cause or the last follow-up. The laboratory and pathologic results of the deceased and surviving patients were compared.

Statistical analysis was performed with SPSS version 22 (demo version, IBM). Nominal data were expressed as percentages. Normality of data were tested with one sample Kolmogorov-Smirnov and or ShapiroWilk tests. Normally distributed continuous data were expressed as means \pm standard deviation, and non-normally distributed continuous data as median (interquartile range [IQR]). Mean survival time was shown as mean \pm standard error $(95 \%$ confidence interval $[95 \% \mathrm{Cl}]$ ). Chi-square, t test, and MannWhitney $U$ tests were used where appropriate. Kaplan-Meier analysis was performed for survival 
analysis. Comparisons between groups with respect to survival were performed using the log-rank test. Cox regression analysis was used to determine the independent predictors of OS. A receiver operating characteristic (ROC) curve was constructed to find a cut-off value whenever appropriate. A $p$ value of $\leq$ .05 was considered statistically significant.

\section{RESULTS}

The clinicopathologic characteristics of all the patients were depicted in Table 1. The mean age was $63.4 \pm 6.8$ years with a male to female ratio of 1:1.29 $(62.4 \pm 5.8$ years in deceased patients vs $64.1 \pm 5.8$ years in survivors, $p=0.638)$. Seven patients $(43.75 \%)$ died during the study period. The most common reason for death was restrictive cardiomyopathy associated with amyloidosis ( $n: 3 / 7)$ followed by amyloidosis associated chronic renal failure $(n: 2 / 7)$. One patient died due to congestive heart failure which was not associated with amyloidosis and one patient died due to gastrointestinal bleeding. Gastrointestinal complaints were

Table 1. Clinicopathological features of light chain amyloidosis patients.

\begin{tabular}{|c|c|c|c|c|c|c|c|c|}
\hline Age (D) & Sex & Syptoms & Biopsy & Bone Marrow & Serum IF & Chemotherapy & Ex $(R)$ & os \\
\hline 67 & $\mathrm{~F}$ & $\begin{array}{l}\text { Backache, dyspepsia, generalized } \\
\text { bone pain }\end{array}$ & Stomach & $\begin{array}{l}\text { IgG lambda } \\
\text { myeloma }\end{array}$ & IgG lambda MG & VCD & $+(\mathrm{CRF})$ & 1 \\
\hline 73 & $\mathrm{~F}$ & $\begin{array}{l}\text { Leg swelling, numbness weight loss, } \\
\text { hoarseness bruising on body }\end{array}$ & $\begin{array}{l}\text { Myocard } \\
\text { Lympho node }\end{array}$ & $\begin{array}{l}\text { Amyloid }(-) \\
<10 \% \text { atypical plasma cells }\end{array}$ & IgG lambda MG & - & - & 28 \\
\hline 59 & $\mathrm{M}$ & $\begin{array}{l}\text { Weakness, } \\
\text { lymphadenopathy on neck }\end{array}$ & Myocard & Amyloid (+) & IgM kappa MG & RBORD & - & 96 \\
\hline 63 & $\mathrm{~F}$ & Imbalance & Kidney & - & Suspected staining & $\begin{array}{l}\text { Colchium on } \\
\text { ilbda column }\end{array}$ & - & 67 \\
\hline 67 & $\mathrm{~F}$ & $\begin{array}{l}\text { Edema and echymosis on ligs, } \\
\text { papillary atrophy on tongue, } \\
\text { hepatomegaly, }\end{array}$ & $\begin{array}{l}\text { Liver, } \\
\text { stomach }\end{array}$ & $\begin{array}{l}\text { Kappa light chain myeloma, } \\
15 \% \\
\text { atypical plasma cells, Amploid } \\
(+)\end{array}$ & No gammopathy & - & - & 28 \\
\hline 56 & $\mathrm{~F}$ & $\begin{array}{l}\text { Nausea, dyspepsia, } \\
\text { Weight loss, effusion in } \\
\text { knees Abdominal swelling }\end{array}$ & Kidney & $\begin{array}{l}80 \% \text { plasma cell infiltration, } \\
\text { myeloma }\end{array}$ & Lambda light chain & VAD & $+(\mathrm{CRF})$ & 1 \\
\hline 59 & M & $\begin{array}{l}\text { Shortness of breath, } \\
\text { numbness of feet, } \\
\text { polyneuropathy, pleuresia, } \\
\text { hypertrophic cardiomyopathy }\end{array}$ & Kidney & $5-10 \%$ plasma cells & IgG lambda MG & VCD & $+(\mathrm{CHF})$ & 60 \\
\hline 52 & $\mathrm{~F}$ & Gastrointestinal bleeding & - & Amploid (+) few plasma cells & No gammopathy & - & $+(\mathrm{G} \mid \mathrm{B})$ & 2 \\
\hline 63 & M & $\begin{array}{l}\text { Diarrhea, weight loss, } \\
\text { Shortness of breath }\end{array}$ & Myocard & Amyloid (+), $0.4 \%$ plasma cells & No gammopathy & - & - & 27 \\
\hline 65 & $\mathrm{~F}$ & $\begin{array}{l}\text { Shortness of breath, } \\
\text { restrictive cardiomyopathy }\end{array}$ & Duodenum & $\begin{array}{l}15 \% \text { Atypical } \\
\text { plasma cells }\end{array}$ & Lambda light chain & - & $+(\mathrm{CHF})$ & 8 \\
\hline 61 & $\mathrm{~F}$ & Anorexia, nausea, vomitting & $\begin{array}{l}\text { Iliopsoas } \\
\text { muscle }\end{array}$ & $\begin{array}{l}\text { Kappa light chain, plasma cell } \\
\text { infiltration }\end{array}$ & Kappa light chain & $\begin{array}{l}\text { VAD, VCD, } \\
\text { Revlimid }\end{array}$ & $+(\mathrm{CHF})$ & 24 \\
\hline 54 & M & $\begin{array}{l}\text { Shortness of breath, } \\
\text { pretibial edema }\end{array}$ & $\begin{array}{l}\text { Myocard, fat } \\
\text { tissue }\end{array}$ & $10 \%$ plasma cells & IgG lambda MG & $\begin{array}{l}\text { VCD, } \\
\text { autotransplant }\end{array}$ & - & 28 \\
\hline 61 & $\mathrm{M}$ & Weight loss, constipation, neck pain & $\begin{array}{l}\text { Lymph node, } \\
\text { Tonsil }\end{array}$ & Normal & IgG lambda MG & VCD & - & 93 \\
\hline 70 & M & Shortness of breath & - & Amyloid (+) & No gammopathy & - & - & 66 \\
\hline 67 & $\mathrm{~F}$ & $\begin{array}{l}\text { Dyspepsia, abdominal pain, leg } \\
\text { swelling, muscle weakness }\end{array}$ & Kidney & 8-9\% plasma cell & Lambda light chain & Colchium & - & 64 \\
\hline 77 & $\mathrm{M}$ & $\begin{array}{l}\text { Shortness of breath, } \\
\text { abdominal pain, } \\
\text { hepatosplenomegaly }\end{array}$ & $\begin{array}{l}\text { Myocard, } \\
\text { colon }\end{array}$ & Normal & No gammopathy & VD & $+(\mathrm{CHF})$ & 1 \\
\hline
\end{tabular}

M: male, F: Female, Age(R): Age at diagnosis, SerumIF: serum immunofixation, Ex (R): Exitus (Reason), Ig: immunoglobulin, MG: monoclonal gammopathy, VAD: Vincristine, doxorubicin, dexamethasone, VCD: bortezomib, cyclophosphamide, dexamethasone, R-BORD: Rituximab, bortezomib, lenalidomide, dexamethasone, CRF: Chronic renal failure, CHF: Congestive heart failure, GIB: Gastrointestinal bleeding. 
the most common symptoms (50\%) followed by shortness of breath (37.5\%), swelling/edema of the lower extremities (31.3\%) and weight loss (25\%). Myocardial and renal biopsies were amyloid- positive in $31.3 \%$ and $25 \%$ of the patients respectively. Bone marrow analyses resulted in detection of myeloma in $18.8 \%$ and amyloid-positivity in $31.3 \%$ of the bone marrow biopsy specimens. Immunoglobulin (IgG) lambda monoclonal gammopathy was found to be the most common form $(50 \%)$ in immunofixation blood tests. Various treatment regimens were given, VCD being the most common treatment regimen (Table 1). Autologous stem cell transplantation was performed in one patient.

The laboratory findings of the patients are depicted in Table 2. Except IgM, no significant difference was found in the laboratory results between the surviving and deceased patients (median [IQR]: 83 [1016.1] vs 65 [54], $p=0.042$ ). Although not significant neutrophilto- lymphocyte ratio, $\mathrm{LDH}$, creatinine and C-Reactive protein were found to be higher and sedimentation rate was lower in the deceased patients (Table 2).
Proteinuria was present in 8 patients with a median value of $350 \mathrm{mg} / \mathrm{L} / \mathrm{day}$ (IQR: $1797.5 \mathrm{mg} / \mathrm{dL}$ ). The most common monoclonal gammopathy in the urine immune electrophoresis was found to be kappa light chain ( $n: 4)$. Correlation analysis showed a significant correlation between OS and LDH and IgM (Spearman's rho correlation coefficient: $-0.673, p=0.006$ for $L D H$, Spearman's rho correlation coefficient: 0.586, $\mathrm{p}=0.0017$ for $\operatorname{lgM})$. When the systemic involvement were grouped as gastrointestinal, cardiac, renal and lymph node involvements, and mortality rates were compared with respect to system involved, it was found that death occurred in cases with gastrointestinal $(67 \%)$, cardiac $(42.7 \%)$, lymph node $(50 \%)$ and renal $(33.3 \%)$ involvement $\left(\chi^{2}\right.$ test, $\left.p=0.860\right)$.

The estimated cumulative OS was $58.6 \pm 10.8$ months in the studied population (Figure 1). One-, 2- and 5year OS rates were $68.8 \%, 62.5 \%$ and $52.1 \%$ respectively. To determine the factors associated with the OS a Cox regression analysis was carried out. LDH, IgM, NLO, creatinine, C-reactive protein and sedimentation were included in the analysis (Table 3 ). IgM was found

Table 2. Comparison of the laboratory findings of deceased and surviving patients (Data expressed as mean \pm standard deviation or median (interquartile range)).

\begin{tabular}{|c|c|c|c|}
\hline & Surviving (n:9) & Deceased (n:7) & p \\
\hline Hemoglobin $(\mathrm{g} / \mathrm{dL})^{\mathrm{a}}$ & $11.8 \pm 2.8$ & $11.3 \pm 1.8$ & 0.638 \\
\hline Sedimentation $(\mathrm{mm} / \mathrm{hr})^{\mathrm{b}}$ & $54(61.5)$ & $27(28)$ & 0.315 \\
\hline Lactic Dehyrogenase $(\mathrm{U} / \mathrm{L})^{\mathrm{b}}$ & $197(121.5)$ & 266 (192) & 0.054 \\
\hline Creatinine $(\mathrm{mg} / \mathrm{dL})^{\mathrm{b}}$ & $1(1.23)$ & $3.6(2.93)$ & 0.174 \\
\hline Calcium (mg/dL) & $8.9 \pm 0.9$ & $9.4 \pm 0.9$ & 0.349 \\
\hline$\beta 2$ microglobulin (mg/dL) & $3.2(13.4)$ & $1.8(17.78)$ & 1 \\
\hline Platelet Lymphocyte Ratio ${ }^{b}$ & $121.1(73.6)$ & $100.7(113.7)$ & 0.536 \\
\hline Neutrophil Lymphocye Ratio ${ }^{b}$ & $1.95(1.39)$ & $3.2182 .26)$ & 0.42 \\
\hline C-Reactive Protein (mg/L) ${ }^{\mathrm{b}}$ & $11.2(15.9)$ & $17.7(29.1)$ & 0.232 \\
\hline Mean Platelet Volume (fl) ${ }^{a}$ & $7.9 \pm 1.9$ & $8.2 \pm 1.2$ & 0.810 \\
\hline Red Cell Distribution Width (\%) & $15.6 \pm 2.9$ & $15.5 \pm 1.7$ & 0.955 \\
\hline Immunoglobulin G (mg/dL) ${ }^{b}$ & 879 (1172.5) & $703(721)$ & 0.606 \\
\hline Immunoglobulin A (mg/dL) & $139(297)$ & $90(214)$ & 0.351 \\
\hline Immunoglobulin $\mathrm{M}(\mathrm{mg} / \mathrm{dL})^{\mathrm{b}}$ & $83(1016.1)$ & $65(54)$ & $0.042 *$ \\
\hline
\end{tabular}

${ }^{a}:$ Student $t$ test; ${ }^{b}:$ Mann - Whitney $U$ test, ${ }^{*}$ : statistically significant

Table 3. Cox regression model for identification of factors related to overall survival: Analysis of maximum likelihood estimates.

\begin{tabular}{|c|c|c|c|c|}
\hline \multirow[b]{2}{*}{ Immunoglobulin $\mathrm{M}$} & \multirow{2}{*}{$\begin{array}{c}\boldsymbol{\beta} \\
-0.231\end{array}$} & \multirow{2}{*}{$\begin{array}{c}\mathbf{p} \\
0.048^{*}\end{array}$} & \multicolumn{2}{|c|}{ Hazard Ratio $95 \% \mathrm{Cl}$} \\
\hline & & & 0.794 & $0.632-0.998$ \\
\hline $\mathrm{LDH}$ at treatment & -0.048 & 0.054 & 0.953 & $0.908-1.001$ \\
\hline Sedimentation rate & -0.287 & 0.056 & 0.750 & $0.559-1.008$ \\
\hline Creatinine & 3.382 & 0.055 & 29.42 & $0.924-936.85$ \\
\hline $\mathrm{C}$ reactive protein & 0.043 & 0.105 & 1.044 & $0.991-1.100$ \\
\hline NLR & -1.689 & 0.075 & 0.185 & $0.029-1.189$ \\
\hline
\end{tabular}

NLR: Neutrophil to lymphocyte ratio, LDH: Lactic dehydrogenase, *: statistically significant 


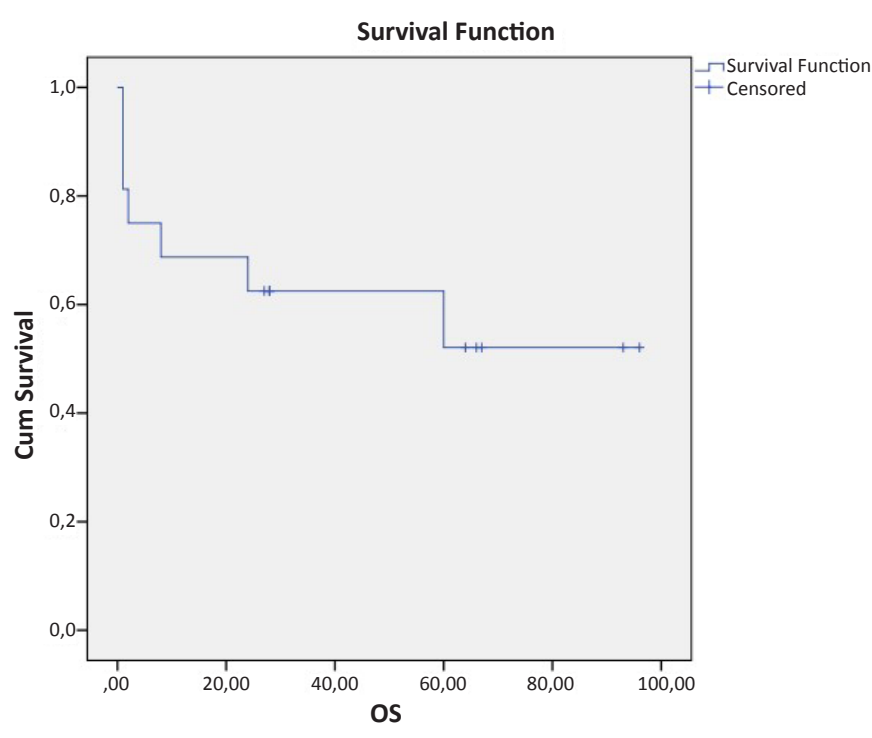

Figure 1. The overall survival (OS) in patients with AL amyloidosis.

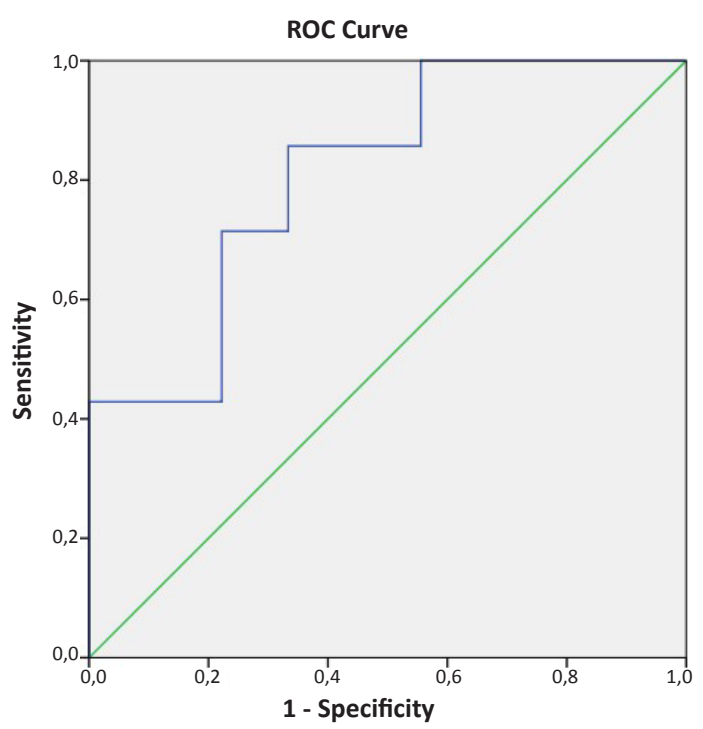

Figure 2. ROC curve for Immunoglobulin $M$ with respect to survival. to be an independent predictor of OS with a hazard ratio of 0.794 ( $p=0.048)$. A ROC analysis was carried out to find a cut- off value for IgM to predict survival (Figure 2). Area under the curve was found to be 0.810 with a standard error of $0.110(\mathrm{p}=0.039,95 \% \mathrm{Cl}$ : $0.595-1.00$ ). An IgM value of $75.4 \mathrm{mg} / \mathrm{dL}$ was found as a cut-off value with a sensitivity and specificity of $71.4 \%$ and $66.7 \%$ respectively for prediction of survival status.

\section{DISCUSSION}

Amyloidosis is a relatively rare disorder and currently there are very few epidemiologic data from our country. This study was conducted in order to present the relevant data on AL amyloidosis and to draw attention to this subtle, progressive disease which can be controlled and treated with early diagnosis.

The main challenge is the diagnosis of this systemic disease because it may affect almost every organ and therefore there are no specific symptoms and signs which in turn causes delay in the diagnosis. The most common symptom was found to be gastrointestinal symptoms including dyspepsia, nausea, diarrhea which was seen in $50 \%$ of the patients. Respiratory symptoms, swelling/edema of the lower extremities and weight loss are the other most frequently observed symptoms. Heart and the kidneys are reported to be the most frequently affected organs ${ }^{(12,13)}$. Cardiac symptoms develop in $50 \%$ of the $\mathrm{AL}$ amyloidosis patients due to deposition of amyloid in heart resulting in progressive restrictive cardiomyopathy and cardiac involvement is considered to be the major cause of mortality with a 5-year survival of $<10 \%{ }^{(13,14)}$. In the present study 3 of the 7 deceased patients had cardiac involvement and the 5 -year survival among patients with cardiac involvement was $35.7 \%$. The main cause of death in these patients was restrictive cardiomyopathy associated with amyloidosis. Peripheral neuropathy is also a common presenting symptom, seen in about $50 \%$ of the patients ${ }^{(7)}$. Autonomic nervous system involvement may result in delayed gastric emptying and intestinal motility disorders and may be another cause of the gastrointestinal symptoms which were most frequently detected in the present study. Because there are no specific diagnostic imaging, blood or urine tests ${ }^{(15)}$, it is recommended that $\mathrm{AL}$ amyloidosis should be suspected in patients with non-diabetic nephrotic syndrome, non-ischemic cardiyomyopathy, polyneuropathy with monoclonal protein, hepatomegaly, increased ALP with normal liver imaging or when a monoclonal gammopathy is present in a patient with unexplained edema, weight loss, fatigue or paresthesia ${ }^{(16-18)}$.

The most common type of gammopathy in AL amyloidosis is reported to be the lambda isotype which has a 3:1 ratio to kappa ${ }^{(19)}$. In the present study 
there were 9 lambda and 2 kappa gammopathies at a 4.5/1 ratio which is not different from that reported in the literature. AL amyloidosis and lambda light -chain gammopathy have been reported to have a tendency for renal involvement due to the interaction of mesangial cells derived from the 6 a germ-line gene ${ }^{(20)}$. In the present study in $66.7 \%(n: 2 / 3)$ of the only lambda light- chain cases renal involvement was detected.

In $\mathrm{AL}$ amyloidosis bone marrow biopsy is performed to exclude multiple myeloma or other disorders such as Waldenström's macroglobulinemia ${ }^{(21)}$. In bone marrow examination, amyloid deposits were detected in $31.3 \%$ of the patients and the plasma cell burden was less than $15 \%$ in most of the cases. In three cases (18.8\%) multiple myeloma was diagnosed and this was also similar to the literature reporting presence of multiple myeloma in $10-15 \%$ of AL amyloidosis patients ${ }^{(12)}$

Systemic inflammatory response markers including NLR, PLR, CRP, RDW and MPV were also analyzed and the levels of these markers were similar between the surviving and deceased patients. RDW and MPV were assessed previously in AA amyloidosis; however, their levels have not been studied in AL amyloidosis up to now ${ }^{(22)}$. Erdem et al. showed that MPV was decreased and RDW was increased in AA amyloidosis due to chronic inflammation ${ }^{(22)}$. The MPV and RDW values found in AA patients were similar to those of our AL patients. NLR and PLR values have not been reported for AL amyloidosis before. Elevated levels of these markers have been reported to be associated with many clinical conditions including cardiovascular diseases, malignancies, cirrhosis, ulcerative colitis and adverse events in pregnancy ${ }^{(23-26)}$. In their study Uslu et al showed that a NLR value $>2.21$ was associated with development of amyloidosis in Familial Mediterranean Fever patients ${ }^{(23)}$. The normal values of NLR in 60-69 year-old Turkish men and women were reported to be $2.41 \pm 1.54$ and $2.09 \pm 1.4$ respectively ${ }^{(27)}$, which is lower than the mean NLR $(2.8 \pm 1.8)$ in this study. NLR was even higher in the deceased patients. The PLR values in 60-69 year- old Turkish healthy patients have been reported to be $101 \pm 82$ and this value was again lower than $118.8 \pm 49.3$ which was found in $\mathrm{AL}$ amyloidosis patients in this study ${ }^{(28)}$. As is indicated, NLR and PLR levels increase in AL amyloidosis patients, however they are not independent predictors of survival.

The only significant factor related to the overall survival was found to be $\lg M$ in this studied population. All IgG, $A$ and $M$ levels were lower in deceased patients; only IgM was a significant marker for survival. There is evidence that levels of immunoglobulins are correlated with prognosis and spread of disease in some cancer types ${ }^{(29)}$. Ig plays an important role in humoral immunity and Tsavardis et al showed that gastric cancer patients with increased levels of IgM have a longer survival ${ }^{(29)}$. Low gammaglobulins have been purposed as risk factors for development of lymphoma in Sjögren's syndrome ${ }^{(30,31)}$. In other studies low IgM but not IgG was associated with progression to lymphoma in Sjögren's syndrome (32,33). These results show that low IgM levels are associated with poor prognosis in various clinical situations. In the present study we have showed for the first time that AL amyloidosis may be one of these disorders. Lower IgM levels may be associated with lower OS. It is true that the pathophysiology of these diseases is different from that of AL. However, in the literature it has been shown that IgM fraction in intravenous IgGAM can play a distinct role in controlling inflammatory and autoimmune diseases and it can reduce oxidative stress which is associated with heart failure, cardiomyopathy and myocarditis ${ }^{(34-40)}$. From this point of view, it would be logical to assume a protective role of IgM especially in cardiac diseases including heart failure. In the present study the most common cause of death was restrictive cardiomyopathy and low IgM levels were associated with OS. This finding needs to be assessed in additional studies performed with greater number of $A L$ amyloidosis cases in order to establish the prognostic value of IgM in such patients.

In addition to the drawbacks related its retrospective design, the main limitation of this study was the small sample size due to the relative rarity of the investigated disorder. The main strength of the study was that it was conducted in a single tertiary center and all the diagnostic and treatment procedures were uniform.

In conclusion AL amyloidosis is a rare, progressive, systemic disease with a wide spectrum of clinical 
presentations. The most important challenge is the diagnosis. The disease most commonly presents with gastrointestinal and respiratory complaints. Except MPV, systemic inflammatory response markers are slightly elevated. Ig $M$ level seems to be an independent predictor of survival and may be used as a prognostic marker.

Ethics Committee Approval: Approval was obtained from Başkent University Medicine and Health Sciences Research Board (20.08.2019 / KA19/284).

Conflict of interests: None.

Funding: None.

Informed Consent: It is a retrospective study.

\section{REFERENCES}

1. Gertz MA, Lacy MQ, Dispenzieri A. Amyloidosis: recognition, confirmation, prognosis, and therapy. Mayo Clin Proc. 1999;74(5):490-4. https://doi.org/10.4065/74.5.490

2. Skinner M, Sanchorawala V, Seldin DC, Dember LM, Falk RH, Berk JL, et al. High-dose melphalan and autologous stem-cell transplantation in patients with AL amyloidosis: An 8-year study. Ann Intern Med. 2004;140(2):85-93. https://doi.org/10.7326/0003-4819-140-2-200401200-00008

3. Dubrey SW, Cha K, Skinner M, LaValley M, Falk RH. Familial and primary (AL) cardiac amyloidosis: echocardiographically similar diseases with distinctly different clinical outcomes. Heart. 1997;78(1):74-82. https://doi.org/10.1136/hrt.78.1.74

4. Desport E, Bridoux F, Sirac C, Delbes S, Bender S, Fernandez B, et al. Al amyloidosis. Orphanet J Rare Dis. 2012;7:54. https://doi.org/10.1186/1750-1172-7-54

5. Gertz MA, Lacy MQ, Dispenzieri A. Amyloidosis. Hematol Oncol Clin North Am. 1999;13(6):1211-33. https://doi.org/10.1016/S0889-8588(05)70122-

6. D’Aguanno V, Ralli M, Artico M, Russo FY, Scarpa A, Fiore $\mathrm{M}$, et al. Systemic amyloidosis: a contemporary overview. Clin Rev Allergy Immunol. 2019 Aug 2. https://doi.org/10.1007/s12016-019-08759-4

7. Wechalekar AD, Gillmore JD, Hawkins PN. Systemic amyloidosis. Lancet. 2016;387(10038):2641-54. https://doi.org/10.1016/S0140-6736(15)01274-X

8. Merlini G, Bellotti V. Molecular mechanisms of amyloidosis. N Engl J Med. 2003;349(6):583-96. https://doi.org/10.1056/NEJMra023144

9. Sipe JD, Benson MD, Buxbaum JN, Ikeda S, Merlini G, Saraiva MJ, et al. Amyloid fibril protein nomenclature: 2012 recommendations from the Nomenclature Committee of the International Society of Amyloidosis. Amyloid. 2012;19(4):167-70. https://doi.org/10.3109/13506129.2012.734345

10. Gertz MA, Comenzo R, Falk RH, Fermand JP, Hazenberg BP, Hawkins PN, et al. Definition of organ involvement and treatment response in immunoglobulin light chain amyloidosis ( $\mathrm{AL}$ ): a consensus opinion from the 10th
International Symposium on Amyloid and Amyloidosis, Tours, France, 18-22 April 2004. Am J Hematol. 2005;79(4):319-28.

https://doi.org/10.1002/ajh.20381

11. Gertz MA, Merlini G. Definition of organ involvement and response to treatment in $\mathrm{AL}$ amyloidosis: an updated consensus opinion. Amyloid 2010;17(Suppl 1):48-9. Available from: https://www.researchgate. net/publication/285021111

12. Kyle RA, Gertz MA. Primary systemic amyloidosis: Clinical and laboratory features in 474 cases. Semin Hematol 1995;32:45-9. PMID: 7878478.

13. Falk RH. Diagnosis and management of the cardiac amyloidoses. Circulation. 2005;112(13):2047-60. https://doi.org/10.1161/CIRCULATIONAHA.104.489187

14. Shi J, Guan J, Jiang B, Brenner DA, Del Monte F, Ward $\mathrm{JE}$, et al. Amyloidogenic light chains induce cardiomyocyte contractile dysfunction and apoptosis via a non-canonical p38alpha MAPK pathway. Proc Natl Acad Sci USA. 2010;107(9):4188-93. https://doi.org/10.1073/pnas.0912263107

15. Chee CE, Lacy MQ, Dogan A, Zeldenrust SR, Gertz MA. Pitfalls in the diagnosis of primary amyloidosis. Clin Lymphoma Myeloma Leuk. 2010;10(3):177-80. https://doi.org/10.3816/CLML.2010.n.027

16. Mabru M, Dacher JN, Bauer F. Left ventricular hypertrophy: Cardiac magnetic resonance may help differentiate amyloidosis from hypertrophic cardiomyopathy. Arch Cardiovasc Dis. 2010;103(1): 55-6.

https://doi.org/10.1016/j.acvd.2008.11.006

17. Perfetto F, Moggi-Pignone A, Livi R, Tempestini A, Bergesio F, Matucci-Cerinic M. Systemic amyloidosis: A challenge for the rheumatologist. Nat Rev Rheumatol. 2010;6(7):417-29. https://doi.org/10.1038/nrrheum.2010.84

18. Gertz MA. Immunoglobulin light chain amyloidosis diagnosis and treatment algorithm 2018. Blood Cancer J. 2018;8(5):44. https://doi.org/10.1038/s41408-018-0080-9

19. Sanchorawala V. Light-chain (AL) amyloidosis: diagnosis and treatment. Clin J Am Soc Nephrol. 2006;1(6):133141. https://doi.org/10.2215/CJN.02740806

20. Comenzo RL, Zhang $\mathrm{Y}$, Martinez C, Osman K, Herrera GA. The tropism of organ involvement in primary systemic amyloidosis: contributions of Ig $\mathrm{V}(\mathrm{L})$ germ line gene use and clonal plasma cell burden. Blood. 2001;98(3):714-20. https://doi.org/10.1182/blood.V98.3.714

21. Sanchorawala V, Blanchard E, Seldin DC, O'Hara C, Skinner M, Wright DG. AL amyloidosis associated with B-cell lymphoproliferative disorders: Frequency and treatment outcomes. Am J Hematol. 2006;81(9): 692-5.

https://doi.org/10.1002/ajh.20635

22. Erdem E, Erdem D, Dilek M, Kaya C, Karataş A, Kut E, et al. Red cell distribution width and mean platelet volume in amyloidosis. Clin Appl Thromb Hemost. 2014;20(3):334-7. https://doi.org/10.1177/1076029612462761

23. Uslu AU, Deveci K, Korkmaz S, Aydin B, Senel S, Sancakdar E, et al. Is neutrophil/lymphocyte ratio associated with subclinical inflammation and 
amyloidosis in patients with familial Mediterranean fever? Biomed Res Int. 2013;2013:185317. https://doi.org/10.1155/2013/185317

24. Balta S, Ozturk C. The platelet-lymphocyte ratio: A simple, inexpensive and rapid prognostic marker for cardiovascular events. Platelets. 2015;26(7):680-1. https://doi.org/10.3109/09537104.2014.979340

25. Celikbilek M, Dogan S, Ozbakır O, Zararsız G, Kücük H, Gürsoy S, et al. Neutrophil-lymphocyte ratio as a predictor of disease severity in ulcerative colitis. J Clin Lab Anal. 2013;27(1):72-6. https://doi.org/10.1002/jcla.21564

26. Toprak E, Bozkurt M, Çakmak BD, Özçimen EE, Silahlı $M$, Yumru $A E$, et al. Platelet-to-lymphocyte ratio: $A$ new inflammatory marker for the diagnosis of preterm premature rupture of membranes J Turk Ger Gynecol Assoc. 2017;18(3):122-6. https://doi.org/10.4274/jtgga.2017.0028

27. Aydın I, Ağıllı M, Aydın FN, Kurt YG, Çaycı T, Taş A, et al. Farklı yaş gruplarında nötrofil/lenfosit oranı referans aralıkları. Gülhane Tıp Derg. 2015;57:414-8. https://doi.org/10.5455/gulhane.166398

28. Yurtdaş M, Özdemir M, Aladağ N. Investigation of neutrophil-to-lymphocyte ratio, platelet-to-lymphocyte ratio and mean platelet volume in patients with compensated heart failure. JAREM. 2018;8:67-71. https://doi.org/10.5152/jarem.2018.1632

29. Tsavaris N, Tsigalacis D, Kosmas C, Koufos C, Vaiopoulos $G$, Tzivras $M$, et al. Preliminary evaluation of the potential prognostic value of serum levels of immunoglobulins (IgA, IgM, IgG, IgE) in patients with gastric cancer. Int J Biol Markers. 1998;13(2):87-91. PMID: 9803356.

https://doi.org/10.1177/172460089801300204

30. Talal N, Bunim JJ. The development of malignant lymphoma in the course of Sjögren's syndrome. Am J Med. 1964;36:529-40. https://doi.org/10.1016/0002-9343(64)90101-9

31. Bijlsma JW, Burmester G, da Silva JA, et al, editors. EULAR compendium on rheumatic diseases. London: BMJ Publishing Group; 2009. p. 322.

32. Kimman J, Bossuyt X, Blockmans D. Prognostic value of cryoglobulins, protein electrophoresis, and serum immunoglobulins for lymphoma development in patients with Sjögren's syndrome. A retrospective cohort study. Acta Clin Belg. 2018;73(3):169-181. https://doi.org/10.1080/17843286.2017.1373966

33. Voulgarelis M, Skopouli FN. Clinical, immunologic, and molecular factors predicting lymphoma development in Sjögren's syndrome patients. Clin Rev Allergy Immunol. 2007;32(3):265-74. https://doi.org/10.1007/s12016-007-8001-x

34. Maisch B, Alter P. Treatment options in myocarditis and inflammatory cardiomyopathy: Focus on i. v. immunoglobulins. Herz. 2018;43(5):423-430. https://doi.org/10.1007/s00059-018-4719-x

35. Grönwall C, Silverman GJ. Natural IgM: Beneficial autoantibodies for the control of inflammatory and autoimmune disease? J Clin Immunol. 2014;34 Suppl 1(01):S12-21. https://doi.org/10.1007/s10875-014-0025-4

36. Kishimoto C, Shioji K, Kinoshita M, Iwase T, Tamaki S, Fujii $M$, et al. Treatment of acute inflammatory cardiomyopathy with intravenous immunoglobulin ameliorates left ventricular function associated with suppression of inflammatory cytokines and decreased oxidative stress. Int J Cardiol. 2003;91(2-3):173-8. https://doi.org/10.1016/S0167-5273(03)00002-0

37. Gullestad L, Aass H, Fjeld JG, et al. Immunomodulating therapy with intravenous immunoglobulin in patients with chronic heart failure. Circulation. 2001;103(2): 220-5. https://doi.org/10.1161/01.CIR.103.2.220

38. Aukrust P, Yndestad A, Ueland T, et al. The role of intravenous immunoglobulin in the treatment of chronic heart failure. Int J Cardiol. 2006;112(1):40-5. https://doi.org/10.1016/j.ijcard.2006.05.015

39. Nussinovitch U, Shoenfeld Y. Intravenous immunoglobulin-indications and mechanisms in cardiovascular diseases. Autoimmun Rev. 2008;7(6):445-52. https://doi.org/10.1016/j.autrev.2008.04.001

40. Walpen AJ, Laumonier T, Aebi C, Mohacsi PJ, Rieben R. IgM enriched intravenous immunoglobulin inhibits classical pathway complement activation, but not bacterial killing by human serum. Xenotransplantation. 2004;11(2):141-8. https://doi.org/10.1046/j.1399-3089.2003.00098.x 